\title{
Management and Development of Newborns from Mothers Carrying HBsAg at the El Rapha Polyclinic in Libreville, Gabon
}

\author{
Eliane Kuissi Kamgaing1,2*, Steeve Minto'o Rogombe², Aude-Mariella Lembet Mikolo,,2, \\ Raïssa Koumba Maniaga' ${ }^{2}$ Edmée Mintsa Mi Nkama², Edgar-Brice Ngoungou ${ }^{3}$, Maiga1 ${ }^{1}$ Aité1, \\ Blaise Okissi' ${ }^{1}$, Marcelle Djiomo$^{1}$, Simon Ategbo ${ }^{2}$
}

${ }^{1}$ Polyclinique El Rapha, Libreville, Gabon

${ }^{2}$ Département de Pédiatrie, Université des Sciences de la Santé (USS), Libreville, Gabon

${ }^{3}$ Department of Biostatistics, Université des Sciences de la Santé (USS), Libreville, Gabon

Email: *e.kuissi@gmail.com

How to cite this paper: Kamgaing, E.K., Rogombe, S.M., Mikolo, A.-M.L., Maniaga, R.K., Nkama, E.M.M., Ngoungou, E.-B., Maiga, Aité, Okissi, B., Djiomo, M. and Ategbo, S. (2021) Management and Development of Newborns from Mothers Carrying HBsAg at the El Rapha Polyclinic in Libreville, Gabon. Open Journal of Pediatrics, 11, 468-478.

https://doi.org/10.4236/ojped.2021.113044

Received: August 11, 2021

Accepted: September 12, 2021

Published: September 15, 2021

Copyright $\odot 2021$ by author(s) and Scientific Research Publishing Inc. This work is licensed under the Creative Commons Attribution International License (CC BY 4.0).

http://creativecommons.org/licenses/by/4.0/ (c) (i) Open Access

\begin{abstract}
Introduction: Hepatitis B is a significant public health problem. Infected children $<6$ years represent a risk population of evolution to chronicity. Objective: We aimed to assess newborns' management and outcome from reactive HBs Ag mothers at the El Rapha Polyclinic in Libreville, Gabon. Methodology: Prospective longitudinal study, carried out over four years, including all neonates born from reactive HBsAg mothers admitted in the delivery room. The parameters studied were maternal age, gestation, marital status, pregnancy follow-up, hepatitis $B$ vaccination status, knowledge of hepatitis $B$, anti-Hbc antibodies' levels, HBeAg. For the newborn: term, birth weight, management at birth, and hepatitis B serological status at 12 months. Results: We included 45 newborns. Mothers' mean age was $30.9 \pm$ seven years. In $32.6 \%$ of cases, antenatal consultations were $\leq 4$, and $9.3 \%$ were vaccinated for hepatitis B. Mothers had chronic hepatitis in $74.4 \%$ of cases. All neonates were vaccinated for hepatitis B at birth; $68.9 \%$ received hepatitis B immunoglobulin. At 12 months, $77.8 \%$ had HBs antibody positive, and $6.7 \%$ were HBsAg positive. Conclusion: Hepatitis B prevalence is significant among parturients. It is essential to set up a national strategy for managing the mother-child couple in a context of positive HBsAg.
\end{abstract}

\section{Keywords}

Viral Hepatitis B, Newborn, Management, Evolution, Gabon 


\section{Introduction}

Hepatitis B is a major public health problem. World Health Organization (WHO) estimates that 2 billion people worldwide had signs of infection of the hepatitis B virus (HBV) in 2015 and that 257 million live with $\mathrm{HBV}$, i.e., 3.6\% of the world population, with high endemicity in the regions of the Western Pacific (6.2\%) and Africa (6.1\%). In the same year, hepatitis B caused 887,000 deaths [1]. In these highly endemic areas, HBV transmission is most often from mother to child, and this perinatal transmission is the main cause of chronic HBsAg carriage. Ninety percent of infants infected during the 1st year of life and $50 \%$ of children infected before six years develop a chronic condition. In addition, $25 \%$ of adults infected during childhood die from hepatocellular carcinoma or cirrhosis [1] [2] [3]. Based on these data, it is well established that the prevention of mother-to-child transmission (PMTCT) of HBV plays a key role in reducing the prevalence of the disease. This HBV PMTCT goes through screening in pregnant women, treatment of infected patients. However, the most effective means remains routine immunization of newborns from birth [2]. In our country, there is no system of serosurveillance of hepatitis B and even less a strategy of codified fight against this plague. Through the Expanded Program on Immunization (EPI), the Ministry of Health recommends the HBV vaccine for children from the 6th week of life combined with other antigens. Therefore, we proposed to study the serological profile of mothers carrying HBsAg and assess the management of their newborns at the El Rapha Polyclinic in Libreville to contribute to advocacy for the introduction into our country's EPI vaccine against hepatitis B from birth.

\section{Patients and Methods}

We conducted a prospective, longitudinal and descriptive study carried out over four years from January 2015 to January 2019 at Gynaecology and Neonatology Services of the El Rapha Polyclinic in Libreville, one of the most significant structures private sanitary facilities in Gabon.

The study population consisted of infants from women with HBsAg who were admitted into the delivery room after informed consent from the mothers.

The parameters studied in the mother were age, gestation, marital status, monitoring of pregnancy, hepatitis $\mathrm{B}$ vaccination status, knowledge of hepatitis $B$, the presence of $\mathrm{HIV}$ and viral hepatitis $\mathrm{C}(\mathrm{HCV})$, the level of antibodies $(\mathrm{Ab})$ $\mathrm{HBc}$ and $\mathrm{Ag} \mathrm{HBe}$. For newborns, we collected: the term, the weight, the time to breastfeed, the type of feeding, the use of hepatitis B vaccine and immunoglobulins, and the serological status of hepatitis B by the assay HBsAg at 12 months.

- Definition of cases: we considered as:

o "chronic parturients" with HBV infection, mothers whose serological results were: $\mathrm{HBcAb}$ (IgG) positive, $\mathrm{HBcAb}$ (IgM) negative;

o “acute hepatitis" mothers whose serologies were: $\mathrm{HBcAb}$ (IgM and IgG) positive, $\mathrm{HBeAb}$ positive. 
- Statistical entry and analysis. Data collection was carried out on a pre-established standardized form, data entry and analysis were carried out on Microsoft Excel 2016. We carried out descriptive statistics. The average evaluated the trends in quantitative variables. Quantitative variables were expressed as an average when the distribution of the variable was regular and as a median when the distribution was not. We presented the qualitative variables in numbers and percentages.

\section{Results}

During the study period, 45 newborns from 43 parturients HBsAg positive were included out of 1710 admitted to the delivery room, representing a frequency of $2.5 \%$.

- Characteristics of mothers.

The mean age of the mothers was $30.9 \pm 7$ years (range $16-46$ years). The median number of children (parity) was 2 (range 0 - 5). Among them, $46.5 \%$ had a university education level, and $90.7 \%$ were not vaccinated for hepatitis B. The median number of antenatal consultations (ANC) was 5 (range 0 - 8). Multiple (triple) pregnancy was observed in 1 parturient. Regarding mothers' knowledge about hepatitis B, $55.8 \%$ declared knowing the disease, and $41.9 \%$ knew the transmission modes; this information was obtained during antenatal consultations in $100 \%$ of cases. Table 1 summarizes the characteristics of parturients.

- Serological profile of parturients.

Parturients with chronic HBV infection accounted for $74.4 \%(\mathrm{n}=32)$, among them $84.4 \%(n=27)$ were HBeAg negative and $15.6 \%(n=5)$ HBeAg positive. Acute hepatitis was observed in $25.6 \%(\mathrm{n}=11)$ of cases. A total of 16 mothers (35.5\%) were carriers of HBeAb.

- Characteristics, care, and evolution of newborns.

The mean gestational age was $35.7 \pm 3.7$ weeks, and (range 27SA - 41SA), the sex ratio was 1.1, the average weight was $2511.7 \pm 874.5 \mathrm{~g}$ (range $810-4220 \mathrm{~g}$ ). Hepatitis B vaccination was administered to all infants (100\%) within 24 hours of birth. In $24.5 \%$ of cases, it was administered within the first 6 hours of life. Administration of human Ig anti-hepatitis B was done in $68.9 \%(\mathrm{n}=31)$ of cases; among them, $9(29.1 \%)$ received it in the first 6 hours of life and $9(29.1 \%)$ between the 6th and the 24th hour of life. The administration of Ig was not done in $14(31.1 \%)$ newborns in all cases $(100 \%)$ for financial reasons.

Bottle feeding was immediately chosen by 17 (37.8\%) parturients. The fear of infecting one's newborn was the reason in $100 \%$ of cases. In this group, 12 (70.6\%) newborns were vaccinated at birth and received anti-hepatitis B human Ig. Breastfeeding was observed in $13.3 \%(n=6)$; all newborns in this group had been vaccinated and given human hepatitis B Immunoglobulin. The median time to breastfeed was 12 hours (range 3 - 51 hours).

Mixed feeding was done in $48.9 \%(\mathrm{n}=22)$ of cases. In this group, $40.9 \%(\mathrm{n}=$ 9) of infants had not received human Ig. The mean time to use breast milk in 
Table 1. Characteristics of parturients.

\begin{tabular}{|c|c|c|c|}
\hline \multicolumn{2}{|c|}{ Characteristics } & \multirow{2}{*}{$\begin{array}{c}\text { Number } \\
2\end{array}$} & \multirow{2}{*}{$\begin{array}{c}\text { Percentage (\%) } \\
4.6\end{array}$} \\
\hline & $<18$ & & \\
\hline \multirow[t]{3}{*}{ Age (years) } & $18-35$ & 27 & 62.8 \\
\hline & $>35$ & 14 & 32.6 \\
\hline & Singles & 9 & 20.9 \\
\hline \multirow[t]{3}{*}{ Marital status } & Cohabitation & 15 & 34.9 \\
\hline & Brides & 19 & 44.2 \\
\hline & 0 & 8 & 18.6 \\
\hline \multirow{3}{*}{$\begin{array}{l}\text { Parity } \\
\text { (number of children) }\end{array}$} & $1-2$ & 20 & 46.5 \\
\hline & $3-4$ & 12 & 27.9 \\
\hline & $>4$ & 3 & 7 \\
\hline \multirow{2}{*}{ Hepatitis B vaccine } & Yes & 4 & 9.3 \\
\hline & No/unknown & 39 & 90.7 \\
\hline \multirow{3}{*}{ Level of study } & None/primary & 8 & 18.6 \\
\hline & Secondary & 15 & 34.9 \\
\hline & University & 20 & 46.5 \\
\hline \multirow{3}{*}{ Pregnancy monitoring (ANC) } & 0 - 2 ANC & 3 & 7 \\
\hline & 3 - 4 ANC & 11 & 25.6 \\
\hline & $>4$ ANC & 29 & 67.4 \\
\hline \multirow{2}{*}{ Type of pregnancy } & Unique & 42 & 97.7 \\
\hline & Multiple & 1 & 2.3 \\
\hline \multirow{2}{*}{ Delivery method } & vaginal delivery & 28 & 65.1 \\
\hline & cesarean delivery & 15 & 34.9 \\
\hline \multirow{2}{*}{ Knowledge about hepatitis B } & Yes & 24 & 55.8 \\
\hline & No & 19 & 44.2 \\
\hline \multirow{2}{*}{$\begin{array}{l}\text { Knowledge of the mode of } \\
\text { transmission }\end{array}$} & Yes & 18 & 41.9 \\
\hline & No & 25 & 58.1 \\
\hline HIV co-infection & & 6 & 13.9 \\
\hline HVC co-infection & & 2 & 4.6 \\
\hline
\end{tabular}

these 9 newborns was $112.8 \pm 31.7$ hours (range $26-480$ hours), and 4 (44.4\%) mothers had chronic hepatitis.

At 12 months, $35(77.8 \%)$ of the infants had a negative HBsAg. HBsAg was positive in $6.7 \%(n=3)$ of cases; all of them were from Ag Hbe mother positive, had not received anti-HBB Ig at birth. Of these HBsAg positive infants, two were from mothers with HVB-HIV co-infection and had not been breastfed. In 15.5\% $(\mathrm{n}=7)$, the hepatitis B status was unknown, of which 4 were attrition. Table 2 summarizes the characteristics of the newborns.

\section{Discussion}

The global burden of HBV infection is increasingly recognized; it states in the 20 
Table 2. Characteristics of newborns.

\begin{tabular}{|c|c|c|c|}
\hline \multicolumn{2}{|l|}{ Settings } & \multirow{2}{*}{ Number } & \multirow{2}{*}{$\frac{\text { Percentage (\%) }}{4.5}$} \\
\hline & $<29$ & & \\
\hline Age & $29-32$ & 7 & 15.5 \\
\hline (in weeks of amenorrhea) & $33-36$ & 12 & 26.7 \\
\hline & $\geq 37$ & 24 & 53.3 \\
\hline \multirow{2}{*}{ Sex } & Male & 24 & 53.3 \\
\hline & Feminine & 21 & 46.7 \\
\hline \multirow{4}{*}{$\begin{array}{l}\text { Weight } \\
\text { (in grams) }\end{array}$} & $<1000$ & 1 & 2.2 \\
\hline & $1000-1500$ & 8 & 17.8 \\
\hline & $1500-2400$ & 8 & 17.8 \\
\hline & $\geq 2500$ & 28 & 62.2 \\
\hline \multirow{3}{*}{$\begin{array}{l}\text { Delay of administration of } \\
\text { hepatitis B vaccine } \\
\text { (in hours of life) }\end{array}$} & $\leq 6$ & 11 & 24.5 \\
\hline & $7-24$ & 34 & 75.5 \\
\hline & $>24$ & 0 & 0.0 \\
\hline \multirow{2}{*}{$\begin{array}{l}\text { Human hepatitis B } \\
\text { immunoglobulins administration }\end{array}$} & Yes & 31 & 68.9 \\
\hline & No & 14 & 31.1 \\
\hline \multirow{3}{*}{ Food type } & Breastfeeding & 6 & 13.3 \\
\hline & Artificial milk & 17 & 37.8 \\
\hline & Mixed food & 22 & 48.9 \\
\hline \multirow{5}{*}{$\begin{array}{l}\text { Delay of introducing breast milk } \\
\text { (in hours of life) }\end{array}$} & $0-1$ & 0 & 0.0 \\
\hline & $1-3$ & 1 & 3.6 \\
\hline & $3-12$ & 5 & 17.9 \\
\hline & $12-24$ & 9 & 32.1 \\
\hline & $>24$ & 13 & 46.4 \\
\hline \multirow{3}{*}{ HBsAg at 12 months } & Positive & 3 & 6.7 \\
\hline & Negative & 35 & 77.8 \\
\hline & Unknown & 7 & 15.5 \\
\hline
\end{tabular}

leading causes of human mortality [4], eased by the global diversity of chronic HBV carriage and the disproportionate burden undergone by people living in resource-poor settings. The hepatitis B virus is mainly transmitted through the blood, sex, and from mother to child during childbirth. The primary infection can be asymptomatic or manifest as acute hepatitis. It can be lethal (fulminant hepatitis), cure and confer immunity for life, or become chronic with a potential risk of severe consequences such as chronic hepatopathy, cirrhosis, or liver cancer. Incubation time is long (4 weeks to 6 months), and the infection is frequently asymptomatic [5] [6]. Mother-to-child transmission of the hepatitis $B$ virus is the leading cause of chronic HBsAg carrier; this risk is $10 \%$ to $40 \%$ at birth if the mother is positive for $\mathrm{HBsAg}$, reaches $70 \%$ to $90 \%$ if the mother carries the $\mathrm{HBeAg}$ antigen, and drops to $20 \%$ when the mother has already eliminated HBeAg and carries only HBsAg [7] [8] [9]. 
- Characteristics of mothers.

In our study, the average age of the mothers is $30.9 \pm 7$ years, and the age group 18 - 35 years was the most observed; they were in a couple (cohabitation or married) in almost $80 \%$ of cases and the average number of children per mother was 2. In $46.5 \%$ of cases, they had a university-level (46.5\%) and had carried out at least 4 ANC (67.4\%). This observation was by several African studies in which the average age of mothers varied from 24 to 34.6 years with the predominant age group of 16 - 46 years, at least a primary school level and housewives for the most part [8] [10] [11] [12] [13]. HBV/HIV co-infection was observed in 13.9\% of the cases in our study; it was $2 \%$ in Burkina Faso 2009 [13] and $1.5 \%$ in Cameroon in 2015 [11]. These data are not insignificant because Mauritania has shown that education, ethnicity, and occupation were significantly associated with exposure to HBV in pregnant women [14] and that co-infection by HIV/HBV increases morbidity and mortality [1]. A previous pregnancy and a full-term delivery were found in most of our parturients, as in El Agheb et al. study in France [8] and Kasia et al. in Cameroon [10]. Only 9.3\% of mothers are vaccinated for hepatitis B in our series, a rate higher than that of Bigna et al. in Cameroon (1.2\%) [11].

- Prevalence of the carrying of HBsAg and serological profile of mothers.

The prevalence of carriage of HBsAg in women giving birth at the El Rapha polyclinic is $2.5 \%$. This hospital prevalence is identical to that observed in central Morocco, where the seroprevalence of $\mathrm{HBsAg}$ in pregnant women was $2.35 \%$ in 2016 [15] and lower than those observed at Lariboisière hospital in 2013, which was $4 \%$ over 7 years, of which the majority of mothers (53\%) are from sub-Saharan Africa [16], in Cameroon in rural areas in 2015 (10.2\%) [11], in Burkina Faso, where prevalence varies between $9.8 \%$ and $11.4 \%$ [13]. In Gabon, HBsAg was present in $9.2 \%$ of pregnant women in 2008 [17], the Estuary Region, which shelters Libreville, $8.8 \%$ of the population were carriers of HBsAg in 2019 [18].

A high rate is also observed in other sub-Saharan countries such as Bangui in the DRC (8.2\%) in 2018 [19], in Mali (15.5\%) [12], in Niger (10.7\%), Mauritania (15\%) [20] and Côte d'Ivoire where it varied from 10\% to $12 \%$ in 2014 [21]. Our findings confirm the overall prevalence of people with HBsAg of 7.4\% in 2019 [18], like other sub-Saharan countries, part of the highly endemic area of 1 hepatitis B described by WHO, in which the prevalence of HBsAg varies from 5 to $8 \%$ [4] [22] [23].

The primary mode of hepatitis B transmission is from mother to child [6] [24] [25]. This perinatal transmission is strongly correlated with the presence of a high viral load in the mother, attested indirectly by the presence or not of HBeAg or directly by the presence of higher DNA $2 \times 105 \mathrm{IU} / \mathrm{ml}$ [7] [8] [9] [26]. In Gabon, the Hbe antigen was found in 10.1\% of pregnant women in 2008 [17]. In our result, $35.5 \%$ of mothers have a positive $\mathrm{HBeAg}$, which is similar to Burkina Faso (31.4\%) [13] and higher than that in Cameroon (12.1\%) [11]. In Mau- 
ritania, the viral load of HBV DNA was more significant than $3 \mathrm{log} I U / \mathrm{ml}$ in $10.1 \%$ of pregnant women [14].

In Burkina Faso, the rate of antenatal transmission of HBV was 37.1\% in 2009, significantly favored by the presence of $\mathrm{HBeAg}$ in the mother, co-infection with HIV, and the fact that the mother was excised [13]. We found that $6.7 \%$ of our new-borns, all from an AgHbe cheerful mother and 2 of whom had not been breastfed (because of HBV/HIV co-infection) were HBsAg positive at 12 months of age, even if Souquière et al. in 2016 in Gabon, had not observed vertical transmission of HBV within families, but rather horizontal intra-family transmission by body fluids in children aged 0 at 10 years old [27].

- Characteristics of newborns, care and development.

As recommended by the WHO, all the newborns of our series received the hepatitis B vaccine at birth, and the administration of human Ig anti-hepatitis B is observed in $68.9 \%$ of cases. This was only possible because the El Rapha polyclinic, being a private structure, receives mainly patients with private or international health insurance, which covers all costs of hospitalization, medicines including those of prevention such as vaccines and human Ig against hepatitis $\mathrm{B}$, the price of which is around 60,000 XAF (100 USD), very expensive for the middle class of the Gabonese population. In $100 \%$ of cases, patients who have not received anti-hepatitis B Ig have no private health insurance or are covered by the National Health Insurance, which remains health insurance more focused on curative than preventive care.

In Gabon, despite the considerable prevalence of HBV infection, the hepatitis $B$ vaccine birth dose is not taken into account in the EPI. However, it is well established that the vaccine coverage rate of pentavalent, which contains the 1st dose of the hepatitis B vaccine (administered from 6 weeks of life), is meager in our country, around $32 \%$ according to the last demographic and health survey of 2012 [28] whereas this rate, which currently peaks at $84 \%$ worldwide, has made it possible to drastically reduce the transmission of HBV during the first five years of life despite the fact that the coverage by the initial dose of vaccine administered at birth remains very low (39\%) [1].

Primary prevention and control of HBV infection require behaviour change, which will only be possible through public information, communication and education, associated with vaccination against hepatitis B initiated from birth [1] [6] [25] [27]. This is correctly arranged in a national hepatitis B control program. The fact that in our study population, almost half of the mothers have no knowledge of hepatitis B (44.2\%) and consequently on the modes of transmission $(58.1 \%)$ can only be justified by this absence of a national hepatitis B control program. However, viral hepatitis is as deadly as tuberculosis, malaria, and more than HIV [1], in a context where the number of deaths due to HBV increases with time and the mortality due to tuberculosis and HIV decreases [1]. This observation is explained by the fact that the HBV infection remains, despite all the progress, a forgotten disease, as Lemoine specifies [29]. In 2011, the "Da- 
kar call" for the fight against viral hepatitis on the African continent marked awareness of this disease and insisted on the seriousness and the extent of the public health problem that they represent [30] and, in 2013, the "Dakar Consensus" issued a number of recommendations for an intensification of the fight, in particular the need for vaccination at birth, access to diagnosis and treatment in the same way as HIV with the appointment in each country of a coordinator of the hepatitis control program [31]. Unfortunately, the disease remains, at this date, poorly taken into account in our national health system and improperly understood by populations in developing countries.

The decrease in hepatitris B prevalence in Western countries is due to socio-economic level improvement, universal vaccination programs, and the introduction of effective antiviral treatments [32], including in pregnant women with high viraemia [33] [34] [35]. Transmission of the virus despite active and passive immunization of the newborn at birth is associated with high maternal viremia [32].

Bottle feeding was immediately chosen by $37.8 \%$ of parturients; the fear of transmission to newborns was the reason in $100 \%$ of cases. This observation raises a question like simply the prohibition of breastfeeding in neonates born from mothers with active HBV in our country. This opinion is led by the fact that we do not have a real strategy for managing this infection in general and specifically in pregnant women, regarding:

- HBV infection is one of the 20 leading causes of human death [4],

- mothers carrying chronic HBV are the reservoir of the mother to child transmission of the infection [15] [36],

- in areas of high endemicity such as ours, the primary mode of transmission is perinatal [6] [24] [25],

- acute hepatitis B infection becomes chronic in more than $90 \%$ of cases in newborns [32],

- absence of vaccination prophylaxis and the administration of immunoglobulins to the new-born, the risk of transmission of $\mathrm{HBV}$ at birth is $70 \%-90 \%$ in the case of acute hepatitis B at the end of pregnancy [7],

- persisting risk of transmission of the virus in 5\% to $10 \%$ despite active and passive immunization of the new-born at birth [32] [37],

- the existence of intra-familial transmission by biological fluids in children aged 0 - 10 years [27],

- and finally, childhood infection is probably the leading risk factor for HBV chronic infections [19].

\section{Conclusion}

The prevalence of hepatitis B was relatively high among pregnant women. The care of the mother-child couple was optimal at the El Rapha Polyclinic because most of the cases' care was backed by private insurance. We showed the possibility to effectively protect neonates born from a reactive HBsAg mother's trans- 
mission in our country. Our findings are a clue to establish a national strategy for the management of newborns in a maternal context of HBsAg positive, and above all, the administration of the first dose of hepatitis $B$ vaccine at birth and hepatitis B immunoglobulins.

\section{Conflicts of Interest}

None.

\section{References}

[1] Organisation mondiale de la santé (OMS) (2017) Rapports mondial sur l'hépatite. https://www.who.int/hepatitis/publications/global-hepatitis-report2017executive..../ $\underline{\mathrm{fr}}$

[2] Organisation mondiale de la santé (OMS) (2019) Hépatite B, principaux faits. https://www.who.int/fr/news-room/fact-sheets/detail/hepatitis-b

[3] McMahon, B.J. (2010) Natural History of Chronic Hepatitis B. Clinical Liver Disease, 14, 381-396. https://doi.org/10.1016/j.cld.2010.05.007

[4] MacLachlan, J.H., Locarnini, S. and Cowie, B.C. (2015) Estimating the Global Prevalence of Hepatitis B. The Lancet, 386, 1515-1517. https://doi.org/10.1016/S0140-6736(15)61116-3

[5] Masserey, S.V., Aebi, C., Matter, L., Boulvain, M. and Bucher, H.U. (2007) Recommandations pour la prévention de la transmission mère-enfant de l'hépatite $\mathrm{B}$. Paediatrica, 18, 21-26.

[6] Franco, E., Bagnato, B., Marino, M.G., Meleleo, C., Serino, L. and Zaratti, L. (2012) Hepatitis B: Epidemiology and Prevention in Developing Countries. World Journal of Hepatology, 4, 74-80. https://doi.org/10.4254/wjh.v4.i3.74

[7] Office fédéral de la santé publique (OFSP) et Commission fédérale pour les vaccinations (CFV) (2019) Recommandations pour la prévention de l'hépatite B. Directives et recommandations. OFSP, Berne.

[8] El Agheb, M.O.M. and Grange, J.D. (2015) Prévention de la transmission mère-enfant de l'hépatite B. The Pan African Medical Journal, 20, Article No. 316.

http://www.panafrican-med-journal.com/content//article/20/316/full https://doi.org/10.11604/pamj.2015.20.316.6193

[9] Rivet, C. and Broué, P. (2012) Hépatite virale B-Pas à Pas en Pédiatrie 2012.

[10] Kasia, J.M., Noa Ndoua, C.C., Kensoung, H. and Belinga, E. (2020) Aspects cliniques et pronostiques de l'Hépatite Virale B en Grossesse au CHRACERH. Health Sciences and Disease, 21, 1-4. https://www.hsd-fmsb.org

[11] Bigna, J.J.R., Noubiap, J.J.N., Nansseu, J.R.N. and Fokom-Domgue, J. (2015) Prevalence, Infectivity and Correlates of Hepatitis B Virus Infection among Pregnant Women in a Rural District of the Far North Region of Cameroon. BMC Public Health, 15, 454. https://doi.org/10.1186/s12889-015-1806-2

[12] Sidibé, S., Sacko, B.Y. and Traoré, I. (2001) Prévalence des marqueurs sérologiques du virus de l'hépatite B chez les femmes enceintes dans le district de Bamako, Mali. Bulletin de la Société de Pathologie Exotique, 94, 339-341.

[13] Sangaré, L., Sombié, R., Combasséré, A.W., Kouanda, A., Kania, D., Zerbo, O., et al. (2009) Transmission anténatale du virus de l'hépatite B en zone de prévalence modérée du VIH, Ouagadougou, Burkina Faso. Bulletin de la Société de Pathologie Exotique, 102, 226-229. 
[14] Mansour, W., Malick, F.Z., Sidiya, A., Ishagh, E., Chekaraou, M.A., Veillon, P., et al. (2012) Prevalence, Risk Factors, and Molecular Epidemiology of Hepatitis B and Hepatitis Delta Virus in Pregnant Women and in Patients in Mauritania. Journal of Medical Virology, 84, 1186-1198. https://doi.org/10.1002/jmv.23336

[15] Sbiti, M., Khalki, H., Benbella, I. and Louzi, L. (2016) Séroprévalence de l'HBsAg chez la femme enceinte dans le centre du Maroc. The Pan African Medical Journal, 24, 187. https://doi.org/10.11604/pamj.2016.24.187.9849

[16] Sellier, P., Maylin, S., Moreno, M., Ricbourg, A., Mazeron, M.C., Lopes, A., et al. (2013) Vertical Hepatitis b Virus Transmission Despite Serovaccination of the New-Born in Highly Viraemic Mono-Infected Mothers from Various Ethnic Origins: A Retrospective Study in Paris, France. Journal of Hepatology, 58, 63-67. https://doi.org/10.1016/S0168-8278(13)60430-4

[17] Makuwa, M., Caron, M., Souquière, S., Malonga-Mouelet, G., Mahé, A. and Kazanji, M. (2008) Prevalence and Genetic Diversity of Hepatitis B and Delta Viruses in Pregnant Women in Gabon: Molecular Evidence That Hepatitis Delta Virus Clade 8 Originates from and Is Endemic in Central Africa. Journal of Clinical Microbiology, 46, 754-756. https://doi.org/10.1128/JCM.02142-07

[18] Groc, S., Abbate, J.L., Le Gal, F., Gerber, A., Tuaillon, E., Albert, J.L., et al. (2019) High Prevalence and Diversity of Hepatitis B and Hepatitis Delta Virus in Gabon. Journal of Viral Hepatitis, 26, 170-182. https://doi.org/10.1111/jvh.12991

[19] Komas, N.P., Ghosh, S., Abdou-Chekaraou, M., Pradat, P., Al Hawajri, N., Manirakiza, A., et al. (2018) Hepatitis B and Hepatitis D Virus Infections in the Central African Republic, Twenty-Five Years after a Fulminant Hepatitis Outbreak, Indicate Continuing Spread in Asymptomatic Young Adults. PLOS Neglected Tropical Diseases, 12, e0006377. https://doi.org/10.1371/journal.pntd.0006377

[20] Mansour, W. (2012) Prévalence et diversité génétique des souches HBV et HDV circulant au Niger et en Mauritanie. Microbiologie et Parasitologie. Université d'Angers. https://tel.archives-ouvertes.fr/tel-00991555

[21] Pourette, D. and Enel, C. (2014) Représentations et vécu de l'hépatite B de patients subsahariens en Côte d'Ivoire et en France. Santé publique, 26, 869-878. https://doi.org/10.3917/spub.146.0869

[22] Organisation Mondiale de la Santé (OMS) (2012) Prévention et lutte contre l'hépatite virale: Cadre pour l'action mondiale. Genève.

http://apps.who.int/iris/bitstream/10665/130013/1/WHO HSE PED HIP GHP 20 12.1 fre.pdf?ua $=1 \& u a=1$

[23] Schweitzer, A., Horn, J., Mikolajczyk, R.T., Krause, G. and Ott, J.J. (2015) Estimations of Worldwide Prevalence of Chronic Hepatitis B Virus Infection: A Systematic Review of Data Published between 1965 and 2013. The Lancet, 386, 1546-1555. https://doi.org/10.1016/S0140-6736(15)61412-X

[24] Antona, D. (2006) L'hépatite B en France: Aspects épidémiologiques et stratégie vaccinale. Hepato-Gastro, 13, 51-61.

[25] Meireles, L.C., Marinho, R.T. and Van Damme, P. (2015) Three Decades of Hepatitis B Control with Vaccination. World Journal of Hepatology, 7, 2127-2132. https://doi.org/10.4254/wjh.v7.i18.2127

[26] Zou, H. (2012) Virologic Factors Associated with Failure to Passive-Active Immunoprophylaxis in Infants Born to HBsAg-Positive Mothers. Journal of Viral Hepatitis, 19, 18-25. https://doi.org/10.1111/j.1365-2893.2011.01492.x

[27] Souquière, S.F., Makuwa, M., Bisvigou, U. and Kazanji, M. (2016) Epidemiological and Molecular Features of Hepatitis B and Hepatitis Delta Virus Transmission in a 
Remote Rural Community in Central Africa. Infection, Genetics and Evolution, 39, 12-21. https://doi.org/10.1016/j.meegid.2015.12.021

[28] Enquête Démographique et de Santé du Gabon 2012: Rapport de synthèse. https://gabon.unfpa.org/sites/default/files/pub-pdf/EDS\%20II\%20-\%20RAPPORT\% 20DE\%20SYNTHESE.pdf

[29] Lemoine, M., Girard, P.M., Thursz, M. and Raguin, G. (2013) Dans l'ombre du VIH/ SIDA: Les maladies oubliées de l'Afrique sub-saharienne. Quels enjeux sanitaires? Quelle responsabilité des bailleurs de fonds? Face à face. 12. http://faceaface.revues.org/792

[30] Hépatites en Afrique. L’appel de Dakar 2011. http://www.hepatitesafrique.org/index.php/l-initiative/l-appel-de-dakar

[31] Hépatites en Afrique. Conférence internationale des acteurs de lutte contre les hépatites en Afrique: Le consensus de Dakar 2013, Dakar (Sénégal). http://www.hepatitesafrique.org/images/docs/consensus/declaration.pdf

[32] Gkouvatsos, K., Goossens, N., Spahr, L. and Negro, F. (2017) Hépatite B: Nouvelles recommandations de prise en charge. Revue Médicale Suisse, 13, 1458-1463.

[33] Schillie, S., Vellozzi, C., Reingold, A., et al. (2018) Prevention of Hepatitis B Virus Infection in the United States: Recommendations of the Advisory Committee on Immunization Practices. MMWR Recommendations and Reports, 67, 1-31. https://doi.org/10.15585/mmwr.rr6701a1

[34] European Centre for Disease Prevention and Control (2017) Antenatal Screening for HIV, Hepatitis B, Syphilis, and Rubella Susceptibility in the EU/ EEA-Addressing the Vulnerable Populations. ECDC, Stockholm.

[35] Brown, R.S., McMahon, B.J., Lok, A.S.F., et al. (2016) Antiviral Therapy in Chronic Hepatitis B Viral Infection during Pregnancy: A Systematic Review and Meta-Analysis. Hepatology, 63, 319-333. https://doi.org/10.1002/hep.28302

[36] Dionne-Odom, J., Tita, A.T. and Silverman, N.S. (2016) Hepatitis B in Pregnancy Screening, Treatment, and Prevention of Vertical Transmission. American Journal of Obstetrics and Gynecology, 214, 6-14. https://doi.org/10.1016/j.ajog.2015.09.100

[37] Del Canho, R., Grosheide, P.M., Mazel, J.A., et al. (1997) Ten-Year Neonatal Hepatitis B, Vaccination Program, The Netherlands, 1982-1992: Protective Efficacy and Long-Term Immunogenicity. Vaccine, 15, 1624-1630.

https://doi.org/10.1016/S0264-410X(97)00080-7 